\title{
MODEL PERHITUNGAN RENTANG DURASI PROBABILISTIK MENGGUNAKAN METODE EARNED SCHEDULE PADA PROYEK DI JAKARTA DAN SEKITARNYA
}

\author{
Shindy ${ }^{1}$ dan Basuki Anondho ${ }^{2}$ \\ ${ }^{\text {I}}$ Program Studi Sarjana Teknik Sipil, Universitas Tarumanagara, Jl.Letjen S. Parman No.1 Jakarta \\ Email: shindyhuang11@gmail.com \\ ${ }^{2}$ Program Studi Sarjana Teknik Sipil, Universitas Tarumanagara, Jl.Letjen S. Parman No.1 Jakarta \\ Email: basukia@ft.untar.ac.id
}

\begin{abstract}
ABSTRAK
Dalam pengelolaan proyek konstruksi, durasi merupakan salah satu komponen yang penting dan mempengaruhi kesuksesan suatu proyek. Akan tetapi akibat unsur ketidakpastian yang terdapat dalam pekerjaan proyek konstruksi mengakibatkan manajer proyek sulit untuk melakukan prediksi durasi akhir proyek konstruksi secara lebih akurat. Pada sisi lain terdapat metode Earned Schedule yang perhitungannya menggunakan indikator berbasis waktu, yakni Schedule Performance Index (SPI), sehingga mendukung dalam perhitungan prediksi durasi akhir proyek konstruksi. Oleh karena itu, pada penelitian ini akan dirancang sebuah model perhitungan rentang durasi probabilistik akhir proyek konstruksi dengan menggunakan metode Earned Schedule. Penelitian ini menggunakan data berupa kurva S dari 45 proyek yang sedang berjalan di Jakarta dan sekitarnya. Penelitian ini dilakukan dengan menghitung angka rata-rata prediksi durasi akhir proyek (EAC) pada masing-masing data proyek, kemudian dilakukan perhitungan interval batas atas dan batas bawah sebagai rentang durasi probabilsitik akhir proyek. Hasil dari penelitian ini menunjukkan bahwa model perhitungan rentang durasi probabilistik akhir proyek dapat digunakan untuk memprediksi durasi akhir proyek yang bersifat probabilistik.
\end{abstract}

Kata Kunci: Earned Schedule, Durasi Probabilistik, Prediksi Durasi.

\begin{abstract}
In management of construction project, duration is one of the important components and affects the success of a project. However, due to the element of uncertainty in the construction project work, it is difficult for project managers to predict the final duration of the construction project more accurately. On the other hand, there is Earned Schedule method which calculations are using time-based indicators, namely Schedule Performance Index (SPI), so it is supporting the calculation of the prediction of the final duration of the construction project. Therefore, in this research will be designed a model calculation of probabilistic duration range of the construction project by using Earned Schedule method. This study uses $S$ curve data of 45 projects on going in Jakarta and surrounding areas. This study was conducted by calculating the average prediction of Estimate at Completion (EAC) on each project data, then calculating the upper and lower limit interval as the probabilistic project duration range. The results of this study indicate that the probabilistic duration of the project duration calculation model can be used to predict the probabilistic duration of the project.
\end{abstract}

Keywords: Earned Schedule, Probabilistik Duration, Duration Estimation.

\section{PENDAHULUAN}

\section{Latar Belakang}

Durasi proyek konstruksi merupakan salah satu faktor kunci yang harus dipertimbangkan saat akan memulai jalannya suatu proyek baru, karena dapat menentukan keberhasilan atau kegagalan suatu proyek konstruksi (Lee, et al., 2009).

Lee, et al. (2009) menyatakan bahwa perencanaan konstruksi saat ini bergantung pada metode penjadwalan deterministik tradisional yang tidak dapat memastikan dengan jelas tingkat ketidakpastian dalam suatu proyek. Hal tersebut menunjukkan bahwa prediksi durasi akhir proyek bersifat probabilistik atau tidak pasti. Kendala yang sering kita temukan yaitu durasi dalam suatu proyek konstruksi sering kali tidak sesuai dengan perhitungan prediksi, sehingga jadwal konstruksi dapat menyimpang dari rencana awal. 
Salah satu metode yang banyak digunakan untuk memprediksi durasi akhir proyek adalah Earned Value Method (EVM). Metode tersebut merupakan metode yang sudah cukup lama berkontribusi dan membantu para manajer proyek dalam mengelola proyek, terutama dalam hal prediksi biaya dan durasi akhir proyek. Akan tetapi dalam perkembangannya, penggunaan Earned Value Method (EVM) dalam memprediksi durasi mendapat kritikan oleh karena perhitungannya yang berbasis biaya (Lipke, et al., 2009). Perhitungan metode tersebut yang menggunakan indikator berbasis biaya dan bukan waktu, dalam memprediksi durasi membuat hasil prediksi durasi dari metode tersebut menjadi diragukan dalam dunia konstruksi. Oleh karena itu dibutuhkan metode baru yang dapat menggantikan Earned Value Method (EVM) dan mengatasi kelemahannya dalam memprediksi durasi akhir proyek.

Salah satu pengembangan dari Earned Value Method (EVM) adalah metode Earned Schedule (ES), merupakan metode yang menggunakan indikator waktu sebagai ganti dari indikator biaya mampu mengatasi kekurangan dari Earned Value Method (EVM) pada penelitian sebelumnya (Vanhoucke, et al., 2015). Perhitungan metode Earned Schedule (ES) yang menggunakan indikator berbasis biaya meningkatkan keandalannya dalam memprediksi durasi akhir proyek, sehingga dalam prediksi durasi metode Earned Schedule (ES) lebih dapat diandalkan dibandingkan dengan metode lainnya.

Pada penelitian ini akan dilakukan perhitungan prediksi durasi probabilistik akhir proyek konstruksi dalam upaya mengatasi unsur ketidakpastian agar prediksi yang dilakukan lebih akurat.

\section{Tujuan Penelitian}

Berdasarkan latar belakang, tujuan dari penelitian ini adalah untuk memperoleh model perhitungan rentang prediksi durasi akhir proyek.

\section{Durasi Probabilistik}

Perhitungan prediksi yang dilakukan dalam suatu proyek konstruksi, baik dalam prediksi biaya akhir proyek maupun prediksi durasi akhir proyek, dapat dilakukan dengan menggunakan dua pendekatan yang berbeda, yakni pendekatan deterministik dan pendekatan probabilistik. Pendekatan deterministik melakukan prediksi biaya akhir proyek dan durasi akhir proyek dengan melihat nilai biaya dan durasi yang paling mungkin, sedangkan pendekatan probabilistik melakukan prediksi biaya akhir proyek dan durasi akhir proyek yang direncanakan berdasarkan variabilitas biaya dan durasi yang melekat pada masing-masing kegiatan proyek (Barraza, et al., 2004).

Dalam pelaksanaan suatu kegiatan, digunakan angka-angka prediksi yang berperan untuk memberikan rentang waktu akibat ketidakpastian dalam suatu pelaksanaan kegiatan. Di bawah ini merupakan angka-angka prediksi kegiatan yang pada umumnya digunakan (Anondho, 2017), dan akan dijelaskan seperti berikut ini:

\section{a. Optimistic duration time (a)}

Apabila sebuah kegiatan dilaksanakan dalam suatu kondisi yang mendukung dan segala sesuatunya berjalan dengan baik, maka kegiatan tersebut akan selesai dalam waktu yang lebih cepat. Waktu tersingkat untuk menyelesaikan suatu kegiatan dapat disebut dengan waktu optimistic (optimistic duration time).

\section{b. Pessimistic duration time (b)}

Apabila sebuah kegiatan dilaksanakan dalam situasi dan kondisi yang kurang baik, terdapat kendala atau tidak mendukung, maka kegiatan tersebut akan selesai dalam waktu yang lebih lama. Waktu yang lebih lama ini dapat disebut dengan waktu pesimistik (pessimistic duration time).

\section{Earned Schedule}

Earned Value Method (EVM), sebuah metode yang sudah cukup lama berkontribusi dalam dunia konstruksi, memiliki kelemahan yakni pemakaian indikator biaya bukan indikator waktu dalam perhitungan prediksi durasi akhir proyek, sehingga pemakaian metode tersebut dalam prediksi durasi akhir proyek menjadi diragukan (Vanhoucke, et al., 2015).

Salah satu pengembangan dari Earned Value Method (EVM) adalah metode Earned Schedule (ES) yang merupakan metode yang menggunakan indikator waktu sebagai ganti dari indikator biaya mampu menghilangkan kekurangan dari metode Earned Value (EVM), sehingga metode Earned Schedule (ES) dapat lebih dipercaya dalam keandalannya memprediksi durasi akhir suatu proyek (Lipke, et al., 2009). Untuk lebih jelas dapat dilihat pada gambar 1 di bawah ini. 


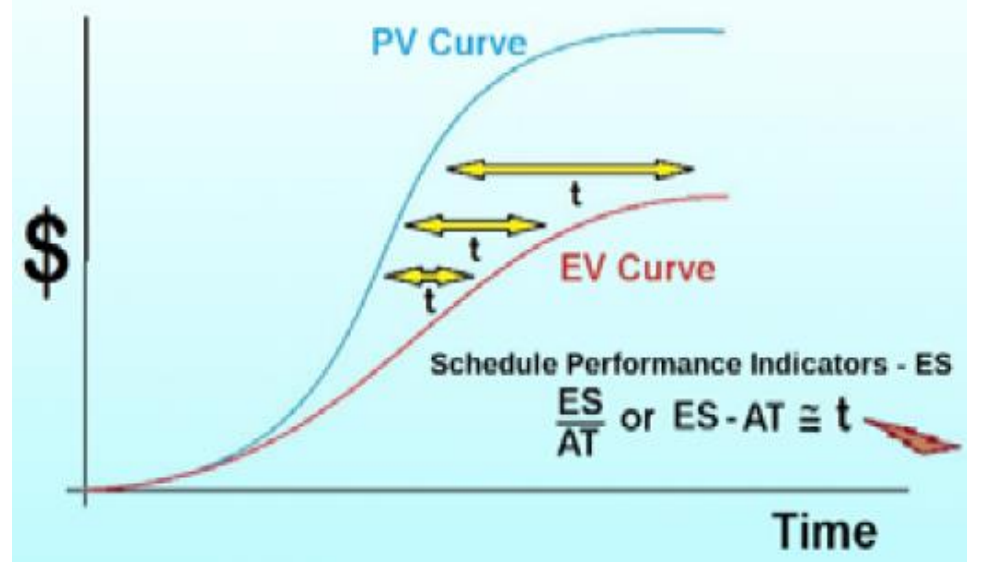

Gambar 1 Prinsip Dasar Pengukuran Kinerja Jadwal dengan ES (Vanhoucke, et al., 2015)

Dalam perhitungan prediksi durasi akhir proyek konstruksi, tentunya membutuhkan beberapa data yang tercantum dalam data kurva $\mathrm{S}$ masing-masing proyek. Berikut ini merupakan data-data yang terdapat dalam kurva $\mathrm{S}$ yang kiranya diperlukan untuk perhitungan prediksi durasi akhir proyek berikut dengan penjelasannya.

1. ACWP (Actual Cost of Work Performed), yaitu jumlah sesungguhnya dari biaya yang dikeluarkan untuk perkerjaan yang telah dilaksanakan sampai saat pengamatan.

2. BCWP (Budgeted Cost of Work Performed), yaitu jumlah anggaran biaya pelaksanaan pekerjaan yang direncanakan pada saat pengamatan yang sesuai dengan kegiatan yang telah dilaksanakan.

3. BCWS (Budgeted Cost of Work Scheduled), yaitu jumlah anggaran biaya pelaksanaan pekerjaan yang direncanakan untuk kegiatan yang direncanakan

Dalam perhitungan prediksi durasi akhir proyek konstruksi, tentu diperlukan beberapa parameter yang digunakan untuk mendapatkan nilai Earned Schedule (ES). Gambaran dari parameter-parameter perhitungan nilai Earned Schedule (ES) tersebut dapat dilihat dan akan dijelaskan seperti pada gambar 2 seperti berikut ini.

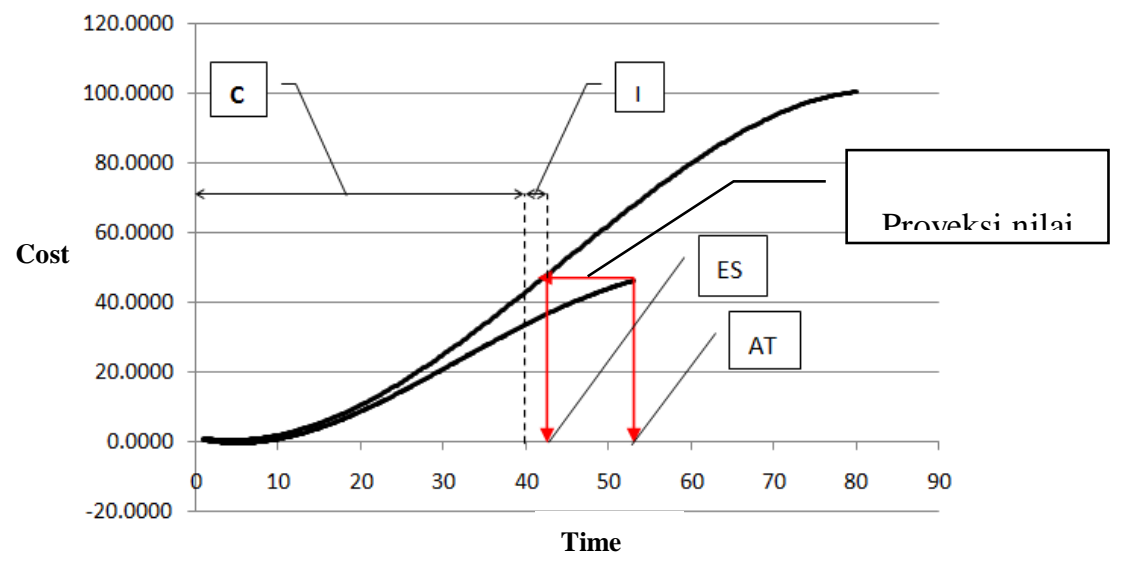

. Gambar 2.2 Parameter Perhitungan Nilai Earned Schedule (ES) (Anondho, 2017)

Nilai Earned Schedule (ES) dapat ditentukan secara grafis dengan mencari suatu titik di mana proyeksi horizontal dari grafik BCWP pada suatu waktu tertentu ke grafik BCWS. Kemudian proyeksi vertikal dari titik proyeksi horizontal sebelumnya terhadap sumbu waktu (time) atau koordinat horizontal merupakan nilai dari Earned Schedule (ES) (Vanhoucke, et al., 2015). Pada gambar 2 di atas terdapat dua indikator utama yang dibutuhkan untuk mendapatkan nilai Earned Schedule (ES), kedua parameter tersebut yakni C dan I (Lipke, et al., 2009). Berikut ini akan dijelaskan masing-masing parameter yang dibutuhkan dalam perhitungan nilai Earned Schedule (ES) tersebut:

1. $\mathrm{C}=$ Nilai atau besaran periode yang dapat ditentukan dengan menghitung jumlah penambahan waktu dari pengukuran kinerja dasar atau Performance Measurement Baseline (PMB) yang memenuhi kondisi, BCWP > BCWS. 
2. $I$ = Nilai hasil interpolasi linear untuk menentukan nilai PMB pada titik yang ditinjau. Untuk mendapatkan nilai I dapat dihitung dengan persamaan sebagai berikut:

$$
\mathrm{I}=\left(\mathrm{BCWP}-\mathrm{BCWS}_{\mathrm{C}}\right) /\left(\mathrm{BCWS}_{\mathrm{C}+1}-\mathrm{BCWS}_{\mathrm{C}}\right)
$$

Selanjutnya dapat diperhitungkan nilai Earned Schedule (ES) dengan rumus yang dijabarkan sebagai berikut:

$$
\mathrm{ES}=\mathrm{C}+\mathrm{I}
$$

Selanjutnya data yang digunakan pada perhitungan metode Earned Schedule (ES) menggunakan perhitungan dengan indikator yang berbasis waktu dan bukan indikator berbasis biaya, indikator-indikator tersebut yaitu Schedule Variance (time) atau SV(t) dan Schedule Performance Index (time) atau SPI(t) (Lipke, 2014). Di bawah ini akan dijelaskan lebih lanjut mengenai kedua indikator tersebut.

a. Schedule Variance (time) atau SV(t)

Schedule Variance (time) atau SV(t) yaitu sebuah indikator yang merupakan nilai selisih antara kinerja yang telah direncanakan pada proyek dengan kinerja realisasi proyek konstruksi. Ketika nilai SV(t) bernilai positif maka berarti kinerja realisasi proyek konstruksi lebih cepat daripada kinerja yang telah dijadwalkan pada proyek, begitu juga sebaliknya apabila nilai SV(t) bernilai negatif berarti kinerja realisasi proyek konstruksi mengalami keterlambatan. Rumus dari Schedule Variance (time) atau SV(t) dapat dijabarkan sebagai berikut:

$$
\mathrm{SV}(\mathrm{t})=\mathrm{ES}-\mathrm{AT}
$$

b. Schedule Performance Index (time) atau SPI(t)

Schedule Performance Index (time) atau SPI(t) yaitu sebuah indikator yang mendeskripsikan besaran efisiensi dalam mecapai Project Duration (PD) untuk waktu yang diinvestasikan. Ketika nilai dari indikator SPI(t) lebih besar atau sama dengan 1, maka kinerja jadwal dapat dinilai baik. Namun sebaliknya, apabila nilai dari indikator SPI(t) lebih kecil daripada 1, berarti dapat disimpulkan bahwa terdapat masalah yang terjadi pada kinerja jadwal sehingga perlu dilakukan investigasi dan diberi koreksi. Rumus dari Schedule Performance Index (time) atau SPI(t) dapat dijabarkan sebagai berikut:

$$
\mathrm{SPI}(\mathrm{t})=\mathrm{ES} / \mathrm{AT}
$$

Keterangan:

AT = Actual Time, yaitu waktu aktual dari awal dimulainya suatu proyek hingga waktu di mana EV diukur.

$\mathrm{ES}=$ Earned Schedule

Besaran nilai prediksi durasi akhir proyek konstruksi dapat diperhitungkan dengan menggunakan rumus yang dijabarkan sebagai berikut:

$$
\mathrm{EAC}(\mathrm{t})=\mathrm{AT}+\frac{\mathrm{PD}-\mathrm{ES}}{\mathrm{SPI}(\mathrm{t})}
$$

Keterangan:

$\mathrm{PD}=$ Project Duration (total durasi proyek)

\section{METODOLOGI PENELITIAN}

\section{Metode Pengumpulan Data}

Pada tahap pengumpulan data dilakukan studi lapangan dengan mengumpulkan data berupa kurva $\mathrm{S}$ proyek yang sedang berjalan (on going) dari berbagai proyek di Jakarta dan sekitarnya. Data berupa kurva $\mathrm{S}$ yang berisikan grafik rencana dan realisasi proyek tersebut dilakukan elaborasi data, yaitu dengan mengeliminasi bobot struktur proyek secara keseluruhan dengan bobot struktur bawah (substructure) untuk mendapatkan bobot realisasi dan rencana baru sebagai data yang akan dipergunakan pada penelitian ini.

Pada tahap ini dilakukan juga studi literatur dari buku dan jurnal mengenai durasi probabilistik dan metode Earned Schedule untuk membantu dalam menganalisis data-data yang telah dikumpulkan pada saat studi lapangan. 


\section{Metode Analisis Data}

Metode analisis yang digunakan untuk menganalisa data menggunakan bantuan microsoft excel untuk membantu perhitungan mulai dari mengelaborasi data-data kurva S proyek, perhitungan Earned Schedule, prediksi durasi akhir proyek, perhitungan rata-rata EAC, hingga perhitungan durasi probabilistik.

\section{ANALISIS DAN PEMBAHASAN}

\section{Hasil Perhitungan Earned Schedule dan Prediksi Durasi Akhir (EAC)}

Berdasarkan data-data kurva S yang telah dilakukan elaborasi, terdapat nilai BCWS dan BCWP untuk perhitungan parameter C dan I. Parameter tersebut digunakan untuk mendapatkan nilai ES. Diperhitungkan juga nilai SPI untuk digunakan dalam perhitungan EAC. Hasil perhitungan Earned Schedule berikut dengan perhitungan prediksi durasi akhir proyek dapat dilihat pada tabel 1 di bawah.

Tabel 1. Hasil Perhitungan Earned Schedule dan EAC

\begin{tabular}{|c|c|c|c|c|c|c|c|c|c|}
\hline $\begin{array}{c}\text { Minggu } \\
\text { ke }\end{array}$ & BCWS & BCWP & BCWSc & $\mathrm{BCWSc}+1$ & $\mathbf{C}$ & I & ES & SPI & EAC \\
\hline 1.0000 & 0.0000 & 0.0000 & 0.0000 & 0.0000 & 0 & 0.0000 & 0.0000 & 0.0000 & 0.0000 \\
\hline 2.0000 & 0.0000 & 0.0000 & 0.0000 & 0.0000 & 0 & 0.0000 & 0.0000 & 0.0000 & 0.0000 \\
\hline 3.0000 & 0.1163 & 0.0000 & 0.0000 & 0.0000 & 0 & 0.0000 & 0.0000 & 0.0000 & 0.0000 \\
\hline 4.0000 & 0.3030 & 0.1854 & 0.1163 & 0.3030 & 3 & 0.3699 & 3.3699 & 0.8425 & 138.8780 \\
\hline 5.0000 & 0.4897 & 0.3708 & 0.3030 & 0.4897 & 4 & 0.3630 & 4.3630 & 0.8726 & 134.0816 \\
\hline 6.0000 & 0.6763 & 0.5562 & 0.4897 & 0.6763 & 5 & 0.3562 & 5.3562 & 0.8927 & 131.0639 \\
\hline 7.0000 & 0.8630 & 0.7383 & 0.6763 & 0.8630 & 6 & 0.3319 & 6.3319 & 0.9046 & 129.3452 \\
\hline 8.0000 & 1.3207 & 1.2509 & 0.8630 & 1.3207 & 7 & 0.8475 & 7.8475 & 0.9809 & 119.2732 \\
\hline 9.0000 & 1.7784 & 1.7185 & 1.3207 & 1.7784 & 8 & 0.8690 & 8.8690 & 0.9854 & 118.7277 \\
\hline 10.0000 & 2.2362 & 2.1930 & 1.7784 & 2.2362 & 9 & 0.9056 & 9.9056 & 0.9906 & 118.1151 \\
\hline 11.0000 & 2.6683 & 2.6208 & 2.2362 & 2.6683 & 10 & 0.8901 & 10.8901 & 0.9900 & 118.1806 \\
\hline 12.0000 & 3.1260 & 3.1228 & 2.6683 & 3.1260 & 11 & 0.9930 & 11.9930 & 0.9994 & 117.0681 \\
\hline 13.0000 & 3.5837 & 3.6325 & 3.5837 & 4.0415 & 13 & 0.1066 & 13.1066 & 1.0082 & 116.0484 \\
\hline 14.0000 & 4.0415 & 3.9567 & 3.5837 & 4.0415 & 13 & 0.8148 & 13.8148 & 0.9868 & 118.5682 \\
\hline 15.0000 & 4.2281 & 4.1223 & 4.0415 & 4.2281 & 14 & 0.4333 & 14.4333 & 0.9622 & 121.5938 \\
\hline 16.0000 & 4.4148 & 4.3970 & 4.2281 & 4.4148 & 15 & 0.9048 & 15.9048 & 0.9940 & 117.7003 \\
\hline 17.0000 & 4.6015 & 4.5663 & 4.4148 & 4.6015 & 16 & 0.8115 & 16.8115 & 0.9889 & 118.3116 \\
\hline 18.0000 & 4.7958 & 4.6954 & 4.6015 & 4.7958 & 17 & 0.4836 & 17.4836 & 0.9713 & 120.4559 \\
\hline 19.0000 & 5.0668 & 4.9654 & 4.7958 & 5.0668 & 18 & 0.6256 & 18.6256 & 0.9803 & 119.3521 \\
\hline 20.0000 & 5.2612 & 5.1794 & 5.0668 & 5.2612 & 19 & 0.5791 & 19.5791 & 0.9790 & 119.5149 \\
\hline 21.0000 & 5.4555 & 5.3585 & 5.2612 & 5.4555 & 20 & 0.5008 & 20.5008 & 0.9762 & 119.8487 \\
\hline 22.0000 & 5.5501 & 5.4570 & 5.4555 & 5.5501 & 21 & 0.0153 & 21.0153 & 0.9552 & 122.4822 \\
\hline 23.0000 & 5.6575 & 5.5511 & 5.5501 & 5.6575 & 22 & 0.0088 & 22.0088 & 0.9569 & 122.2694 \\
\hline 24.0000 & 5.7521 & 5.6433 & 5.5501 & 5.6575 & 22 & 0.8676 & 22.8676 & 0.9528 & 122.7936 \\
\hline 25.0000 & 5.8468 & 5.7090 & 5.6575 & 5.7521 & 23 & 0.5440 & 23.5440 & 0.9418 & 124.2354 \\
\hline 26.0000 & 5.9414 & 5.8049 & 5.7521 & 5.8468 & 24 & 0.5579 & 24.5579 & 0.9445 & 123.8705 \\
\hline
\end{tabular}


Model Perhitungan Rentang Durasi Probabilistik

\begin{tabular}{|c|c|c|c|c|c|c|c|c|c|}
\hline $\begin{array}{c}\text { Minggu } \\
\text { ke }\end{array}$ & BCWS & BCWP & BCWSc & BCWSc+1 & C & I & ES & SPI & EAC \\
\hline 27.0000 & 6.2610 & 6.0619 & 5.9414 & 6.2610 & 26 & 0.3772 & 26.3772 & 0.9769 & 119.7623 \\
\hline 28.0000 & 6.5806 & 6.3249 & 6.2610 & 6.5806 & 27 & 0.2000 & 27.2000 & 0.9714 & 120.4413 \\
\hline 29.0000 & 7.1713 & 6.7296 & 6.5806 & 7.1713 & 28 & 0.2522 & 28.2522 & 0.9742 & 120.0966 \\
\hline 30.0000 & 7.9052 & 7.2148 & 7.1713 & 7.9052 & 29 & 0.0593 & 29.0593 & 0.9686 & 120.7876 \\
\hline 31.0000 & 8.3169 & 7.6795 & 7.1713 & 8.3169 & 29 & 0.4436 & 29.4436 & 0.9498 & 123.1848 \\
\hline 32.0000 & 8.7273 & 8.1061 & 7.9052 & 8.3169 & 30 & 0.4879 & 30.4879 & 0.9527 & 122.8029 \\
\hline 33.0000 & 9.1377 & 8.5119 & 8.3169 & 8.7273 & 31 & 0.4751 & 31.4751 & 0.9538 & 122.6685 \\
\hline 34.0000 & 9.1377 & & & & & & & & \\
\hline 35.0000 & 9.1377 & & & & & & & & \\
\hline 36.0000 & 9.7328 & & & & & & & & \\
\hline 37.0000 & 10.3280 & & & & & & & & \\
\hline 38.0000 & 11.0982 & & & & & & & & \\
\hline 39.0000 & 11.7682 & & & & & & & & \\
\hline
\end{tabular}

\section{Hasil Perhitungan Rata-Rata EAC}

Hasil perhitungan EAC pada langkah sebelumnya akan dilakukan rata-rata setiap proyek sehingga dapat dirangkum pada tabel 2, berikut dengan hasil penyelarasan data satuan.

Tabel 2. Hasil Perhitungan Rata-Rata EAC

\begin{tabular}{|c|c|c|c|c|c|c|}
\hline \multirow{2}{*}{$\begin{array}{c}\text { NAMA } \\
\text { PROYEK }\end{array}$} & \multirow{2}{*}{ DURASI } & \multirow{2}{*}{$\begin{array}{l}\text { SATUAN } \\
\text { WAKTU }\end{array}$} & \multicolumn{2}{|c|}{ EAC/m2 } & \multicolumn{2}{c|}{ EAC/m2/minggu } \\
\hline P1 & & & & & & \\
\hline P2 & 13 & Minggu & 0.003034714 & 0.000983651 & 0.003034714 & 0.000983651 \\
\hline P3 & 27 & Minggu & 0.001287054 & 0.000156948 & 0.001287054 & 0.000156948 \\
\hline P4 & 16 & Bulangu & 0.002592117 & 0.002180676 & 0.002592117 & 0.002180676 \\
\hline P5 & 93 & Minggu & 0.000898874 & 0.000318427 & 0.000898874 & 0.000318427 \\
\hline P6 & 37 & Minggu & 0.00056694 & 0.000303013 & 0.000566694 & 0.000303013 \\
\hline P7 & 37 & Minggu & 0.002981545 & 0.001051286 & 0.002981545 & 0.001051286 \\
\hline P8 & 54 & Minggu & 0.002332671 & 0.000546712 & 0.002332671 & 0.000546712 \\
\hline P9 & 7 & Bulan & 0.000182438 & $8.12524 \mathrm{E}-05$ & 0.000790504 & 0.000352067 \\
\hline P10 & 35 & Minggu & 0.004394142 & 0.00011936 & 0.004394142 & 0.00011936 \\
\hline P11 & 26 & Minggu & 0.000538101 & $4.73936 \mathrm{E}-05$ & 0.000538101 & $4.73936 \mathrm{E}-05$ \\
\hline P12 & 13 & Bulan & 0.00038417 & 0.000196592 & 0.001664608 & 0.000851831 \\
\hline P13 & 17 & Minggu & 0.000416718 & 0.000163138 & 0.000416718 & 0.000163138 \\
\hline P14 & 4 & Bulan & 0.000779012 & $5.55383 \mathrm{E}-05$ & 0.003375457 & 0.000240647 \\
\hline P15 & 48 & Minggu & 0.00183217 & 0.000706327 & 0.00183217 & 0.000706327 \\
\hline
\end{tabular}




\begin{tabular}{|c|c|c|c|c|c|c|}
\hline \multirow{2}{*}{$\begin{array}{c}\text { NAMA } \\
\text { PROYEK }\end{array}$} & \multirow[b]{2}{*}{ DURASI } & \multirow{2}{*}{$\begin{array}{l}\text { SATUAN } \\
\text { WAKTU }\end{array}$} & \multicolumn{2}{|c|}{ EAC/m2 } & \multicolumn{2}{|c|}{ EAC/m2/minggu } \\
\hline & & & Rata-Rata & Standar Deviasi & Rata-Rata & $\begin{array}{l}\text { Standar } \\
\text { Deviasi }\end{array}$ \\
\hline P16 & 33 & Minggu & 0.001100123 & 0.00037035 & 0.001100123 & 0.00037035 \\
\hline P17 & 31 & Minggu & 0.003344954 & 0.000846986 & 0.003344954 & 0.000846986 \\
\hline P18 & 50 & Minggu & 0.002441991 & 0.000190264 & 0.002441991 & 0.000190264 \\
\hline P19 & 19 & Bulan & 0.000796933 & $6.27942 \mathrm{E}-06$ & 0.003453112 & $2.72087 E-05$ \\
\hline $\mathrm{P} 20$ & 55 & Minggu & 0.002510527 & 0.00016015 & 0.002510527 & 0.00016015 \\
\hline $\mathrm{P} 21$ & 23 & Minggu & 0.000844647 & $5.6235 \mathrm{E}-05$ & 0.000844647 & $5.6235 \mathrm{E}-05$ \\
\hline $\mathrm{P} 22$ & 56 & Minggu & 0.001370301 & $7.87572 \mathrm{E}-05$ & 0.001370301 & $7.87572 \mathrm{E}-05$ \\
\hline $\mathrm{P} 23$ & 76 & Minggu & 0.002286297 & 0.000503874 & 0.002286297 & 0.000503874 \\
\hline P24 & 6 & Minggu & 0.000846183 & $8.03844 \mathrm{E}-05$ & 0.000846183 & $8.03844 \mathrm{E}-05$ \\
\hline $\mathrm{P} 25$ & 15 & Minggu & 0.000664391 & $6.07404 \mathrm{E}-05$ & 0.000664391 & $6.07404 \mathrm{E}-05$ \\
\hline $\mathrm{P} 26$ & 9 & Minggu & 0.003733655 & 0.000711263 & 0.003733655 & 0.000711263 \\
\hline $\mathrm{P} 27$ & 31 & Minggu & 0.001275513 & 0.00030263 & 0.001275513 & 0.00030263 \\
\hline P28 & 30 & Minggu & 0.001205928 & 0.000278245 & 0.001205928 & 0.000278245 \\
\hline P29 & 92 & Minggu & 0.00529817 & 0.001727161 & 0.00529817 & 0.001727161 \\
\hline P30 & 19 & Bulan & 0.000148526 & 0.000295246 & 0.000643564 & 0.001279302 \\
\hline P31 & 7 & Bulan & 0.001341501 & 0.001027921 & 0.005812723 & 0.004453983 \\
\hline P32 & 56 & Minggu & 0.002300265 & 0.000746506 & 0.002300265 & 0.000746506 \\
\hline P33 & 103 & Minggu & 0.001032259 & 0.000200848 & 0.001032259 & 0.000200848 \\
\hline P34 & 42 & Minggu & 0.002821965 & 0.000544237 & 0.002821965 & 0.000544237 \\
\hline P35 & 14 & Minggu & 0.002948145 & 0.000995947 & 0.002948145 & 0.000995947 \\
\hline P36 & 40 & Minggu & 0.000792098 & 0.000279828 & 0.000792098 & 0.000279828 \\
\hline P37 & 30 & Minggu & 0.002545756 & 0.004127994 & 0.002545756 & 0.004127994 \\
\hline P38 & 50 & Minggu & 0.005635993 & 0.003572669 & 0.005635993 & 0.003572669 \\
\hline P39 & 53 & Minggu & 0.001570748 & 0.000995701 & 0.001570748 & 0.000995701 \\
\hline $\mathrm{P} 40$ & 17 & Bulan & 0.000222463 & $6.85581 \mathrm{E}-05$ & 0.000963933 & 0.000297062 \\
\hline $\mathrm{P} 41$ & 30 & 2 Minggu & 0.000769436 & 0.000391616 & 0.001538872 & 0.000783232 \\
\hline $\mathrm{P} 42$ & 130 & Minggu & 0.003765125 & 0.000867376 & 0.003765125 & 0.000867376 \\
\hline $\mathrm{P} 43$ & 32 & Bulan & 0.000909158 & 0.000166131 & 0.003939383 & 0.000719846 \\
\hline P44 & 11 & Minggu & 0.029409209 & 0.008219943 & 0.029409209 & 0.008219943 \\
\hline $\mathrm{P} 45$ & 26 & Minggu & 0.008239238 & 0.002200416 & 0.008239238 & 0.002200416 \\
\hline
\end{tabular}

\section{Hasil Perhitungan Durasi Probabilistik}

Setelah didapatkan nilai rata-rata EAC setiap proyek, kemudian dapat diperhitungkan batas atas dan batas bawah tiap proyek. Hasil perhitungan durasi probabiistik dapat dilihat pada tabel 3 berikut. Rata-rata dari keseluruhan batas atas tdan batas bawah setiap proyek merupakan hasil prediksi durasi probabilistik. 
Tabel 3. Hasil Perhitungan Durasi Probabilistik

\begin{tabular}{|c|c|c|c|c|c|c|c|c|}
\hline \multirow{2}{*}{$\begin{array}{c}\text { NAMA } \\
\text { PROYEK }\end{array}$} & \multirow[b]{2}{*}{ DURASI } & \multirow{2}{*}{$\begin{array}{l}\text { SATUAN } \\
\text { WAKTU }\end{array}$} & \multicolumn{2}{|c|}{ EAC/m2 } & \multicolumn{2}{|c|}{ EAC/m2/minggu } & \multicolumn{2}{|c|}{ Interval } \\
\hline & & & $\begin{array}{l}\text { Rata- } \\
\text { Rata }\end{array}$ & $\begin{array}{r}\text { Standar } \\
\text { Deviasi }\end{array}$ & $\begin{array}{l}\text { Rata- } \\
\text { Rata }\end{array}$ & $\begin{array}{l}\text { Standar } \\
\text { Deviasi }\end{array}$ & $\begin{array}{c}\text { Batas } \\
\text { Bawah }\end{array}$ & $\begin{array}{c}\text { Batas } \\
\text { Atas }\end{array}$ \\
\hline P1 & 33 & Minggu & 0.0030 & 0.0010 & 0.0030 & 0.0010 & 0.0027 & 0.0034 \\
\hline P2 & 13 & Minggu & 0.0013 & 0.0002 & 0.0013 & 0.0002 & 0.0012 & 0.0014 \\
\hline P3 & 27 & Minggu & 0.0026 & 0.0022 & 0.0026 & 0.0022 & 0.0018 & 0.0034 \\
\hline $\mathrm{P} 4$ & 16 & Bulan & 0.0002 & 0.0000 & 0.0008 & 0.0001 & 0.0008 & 0.0009 \\
\hline P5 & 93 & Minggu & 0.0009 & 0.0003 & 0.0009 & 0.0003 & 0.0008 & 0.0010 \\
\hline P6 & 37 & Minggu & 0.0006 & 0.0003 & 0.0006 & 0.0003 & 0.0005 & 0.0007 \\
\hline P7 & 37 & Minggu & 0.0030 & 0.0011 & 0.0030 & 0.0011 & 0.0026 & 0.0033 \\
\hline P8 & 54 & Mir & 0.0023 & 0.0005 & 0.0023 & 0.0005 & 0.0022 & 0.0025 \\
\hline P9 & 7 & Bulan & 0.0002 & 0.0001 & 0.0008 & 0.0004 & 0.0005 & 0.0011 \\
\hline P10 & 35 & Minggu & 0.0044 & 0.0001 & 0.0044 & 0.0001 & 0.0044 & 0.0044 \\
\hline P11 & 26 & Minggu & 0.0005 & 0.0000 & 0.0005 & 0.0000 & 0.0005 & 0.0006 \\
\hline P12 & 13 & Bulan & 0.0004 & 0.0002 & 0.0017 & 0.0009 & 0.0012 & 0.0021 \\
\hline P13 & 17 & Minggu & 0.0004 & 0.0002 & 0.0004 & 0.0002 & 0.0003 & 0.0005 \\
\hline P14 & 4 & Bulan & 0.0008 & 0.0001 & 0.0034 & 0.0002 & 0.0031 & 0.0036 \\
\hline P15 & 48 & Minggu & 0.0018 & 0.0007 & 0.0018 & 0.0007 & 0.0016 & 0.0020 \\
\hline P16 & 33 & Minggu & 0.0011 & 0.0004 & 0.0011 & 0.0004 & 0.0010 & 0.0012 \\
\hline P17 & 31 & Minggu & 0.0033 & 0.0008 & 0.0033 & 0.0008 & 0.0030 & 0.0036 \\
\hline P18 & 50 & Minggu & 0.0024 & 0.0002 & 0.0024 & 0.0002 & 0.0024 & 0.0025 \\
\hline P19 & 19 & Bulan & 0.0008 & 0.0000 & 0.0035 & 0.0000 & 0.0034 & 0.0035 \\
\hline P20 & 55 & Minggu & 0.0025 & 0.0002 & 0.0025 & 0.0002 & 0.0025 & 0.0026 \\
\hline P21 & 23 & Minggu & 0.0008 & 0.0001 & 0.0008 & 0.0001 & 0.0008 & 0.0009 \\
\hline P22 & 56 & Minggu & 0.0014 & 0.0001 & 0.0014 & 0.0001 & 0.0013 & 0.0014 \\
\hline P23 & 76 & Minggu & 0.0023 & 0.0005 & 0.0023 & 0.0005 & 0.0022 & 0.0024 \\
\hline P24 & 6 & Minggu & 0.0008 & 0.0001 & 0.0008 & 0.0001 & 0.0008 & 0.0009 \\
\hline P25 & 15 & Minggu & 0.0007 & 0.0001 & 0.0007 & 0.0001 & 0.0006 & 0.0007 \\
\hline P26 & 9 & Minggu & 0.0037 & 0.0007 & 0.0037 & 0.0007 & 0.0033 & 0.0042 \\
\hline P27 & 31 & Minggu & 0.0013 & 0.0003 & 0.0013 & 0.0003 & 0.0012 & 0.0014 \\
\hline P28 & 30 & Minggu & 0.0012 & 0.0003 & 0.0012 & 0.0003 & 0.0011 & 0.0013 \\
\hline P29 & 92 & Minggu & 0.0053 & 0.0017 & 0.0053 & 0.0017 & 0.0049 & 0.0057 \\
\hline P30 & 19 & Bulan & 0.0001 & 0.0003 & 0.0006 & 0.0013 & 0.0001 & 0.0012 \\
\hline P31 & 7 & Bulan & 0.0013 & 0.0010 & 0.0058 & 0.0045 & 0.0025 & 0.0091 \\
\hline P32 & 56 & Minggu & 0.0023 & 0.0007 & 0.0023 & 0.0007 & 0.0021 & 0.0025 \\
\hline
\end{tabular}




\begin{tabular}{|c|c|c|c|c|c|c|c|c|}
\hline \multirow{2}{*}{$\begin{array}{c}\text { NAMA } \\
\text { PROYEK }\end{array}$} & \multirow{2}{*}{ DURASI } & \multirow{2}{*}{ SATUAN } & \multicolumn{2}{|c|}{ EAC/m2 } & \multicolumn{2}{c|}{ EAC/m2/minggu } & \multicolumn{2}{c|}{ Interval } \\
\cline { 5 - 9 } & & WAKTU & $\begin{array}{c}\text { Rata- } \\
\text { Rata }\end{array}$ & $\begin{array}{c}\text { Standar } \\
\text { Deviasi }\end{array}$ & $\begin{array}{c}\text { Rata- } \\
\text { Rata }\end{array}$ & $\begin{array}{c}\text { Standar } \\
\text { Deviasi }\end{array}$ & $\begin{array}{c}\text { Batas } \\
\text { Bawah }\end{array}$ & $\begin{array}{c}\text { Batas } \\
\text { Atas }\end{array}$ \\
\hline P33 & 103 & Minggu & 0.0010 & 0.0002 & 0.0010 & 0.0002 & 0.0010 & 0.0011 \\
\hline P34 & 42 & Minggu & 0.0028 & 0.0005 & 0.0028 & 0.0005 & 0.0027 & 0.0030 \\
\hline P35 & 14 & Minggu & 0.0029 & 0.0010 & 0.0029 & 0.0010 & 0.0024 & 0.0035 \\
\hline P36 & 40 & Minggu & 0.0008 & 0.0003 & 0.0008 & 0.0003 & 0.0007 & 0.0009 \\
\hline P37 & 30 & Minggu & 0.0025 & 0.0041 & 0.0025 & 0.0041 & 0.0011 & 0.0040 \\
\hline P38 & 50 & Minggu & 0.0056 & 0.0036 & 0.0056 & 0.0036 & 0.0046 & 0.0066 \\
\hline P39 & 53 & Minggu & 0.0016 & 0.0010 & 0.0016 & 0.0010 & 0.0013 & 0.0018 \\
\hline P40 & 17 & Bulan & 0.0002 & 0.0001 & 0.0010 & 0.0003 & 0.0008 & 0.0011 \\
\hline P41 & 30 & 2 Minggu & 0.0008 & 0.0004 & 0.0015 & 0.0008 & 0.0013 & 0.0018 \\
\hline P42 & 130 & Minggu & 0.0038 & 0.0009 & 0.0038 & 0.0009 & 0.0036 & 0.0039 \\
\hline P43 & 32 & Bulan & 0.0009 & 0.0002 & 0.0039 & 0.0007 & 0.0037 & 0.0042 \\
\hline P44 & 11 & Minggu & 0.0294 & 0.0082 & 0.0294 & 0.0082 & 0.0246 & 0.0343 \\
\hline P45 & 26 & Minggu & 0.0082 & 0.0022 & 0.0082 & 0.0022 & 0.0074 & 0.0091 \\
\hline
\end{tabular}

Untuk mendapatkan nilai rentang prediksi durasi probabilistic dilakukan perhitungan rata-rata keseluruhan batas atas dan batas bawah. Kedua nilai tersebut akan menjadi rentang durasi probabilistic akhir proyek. Pada penelitian ini didapatkan rentang durasi probabilistic yaitu dengan nilai batas bawah 0.0029 minggu dan batas atas 0.0033 minggu.

\section{KESIMPULAN}

Adapun kesimpulan dari hasil analisis dalam penelitian ini yaitu:

1. Berdasakan hasil yang didapatkan dari perhitungan pada penelitian ini, dapat disimpulkan bahwa model perhitungan rentang prediksi durasi probabilistik akhir proyek konstruksi dapat dipergunakan untuk menghitung tingkat keberhasilan prediksi durasi probabilistik akhir proyek di Jakarta dan sekitarnya.

2. Besaran standar deviasi pada setiap proyek dapat mempengaruhi hasil perhitungan rentang durasi probabilistik. Semakin besar standar deviasi maka semakin baik hasil perhitungan rentang durasi probabilistik.

\section{DAFTAR PUSTAKA}

Anondho, Basuki. (2017). Pengembangan Model Prediksi Durasi Probabilistik Proyek Pengembangan Gedung Bertingkat Tinggi Bertingkat Tinggi Berbasis Faktor Pengaruh Eksternal Terukur. Disertasi. Universitas Indonesia.

Barraza, G. A., Back,W. E., and Mata, F. (2004). Probabilistic Forecasting of Project Performance using Stochastic $S$ Curves, Journal of Construction Engineering and Management.

Barraza, G. A. (2011). Probabilistic Estimation and Allocation of Project Time Contingency, Journal of Construction Engineering and Management.

Batselier, Jordy dan Vanhoucke, Mario. (2015). Empirical Evaluation of Earned Value Management Forecasting Accuracy for Time and Cost, Journal of Constuction Engineering and Management.

Harinaldi. (2005) Prinsip-Prinsip Statistik untuk Teknik dan Sains. Jakarta: Erlangga.

Hyun-soo Lee; Jae-won Shin; Moonseo Park; and Han-Guk Ryu. (2009). Probabilistic Duration Estimation Model for High-Rise Structural Work, Journal of Construction Engineering and Management.

Khamooshi, H. dan Cioffi, F. D. (2013). Uncertainty in Task Duration and Cost Estimates: Fusion of Probabilistic Forecasts and Deterministic Scheduling. Journal of Construction Engineering and Management. 
Model Perhitungan Rentang Durasi Probabilistik

Khamooshi, H dan Abdi, A. (2016). Project Duration Forecasting Using Earned Duration Management with Exponential Smoothing Techniques, Journal of Management in Engineering. Vol. 33, No. 1 (Januari 2017): 110 .

Kim, B., and Reinschmidt, K. (2010). Probabilistic Forecasting Of Project Duration Using Kalman Filter And The Earned Value Method. Journal of Construction Engineering and Management.

Lipke, W., Zwikael, O., Henderson, K., dan Anbari, F. (2009). Prediction Of Project Outcome: The Application Of Statistical Method To Earned Value Management And Earned Schedule Performance Indexes. International Journal of Project Management, 27(2009), 400-407.

Lipke, Walt. (2012). Earned Schedule Contribution to Project Management.Vol. I, Issue II. PM World Journal.

Lipke, Walt. (2014). Testing Earned Schedule Forecasting Reliability. Vol. III, Issue III. PM World Journal.

Lipke, Walt. (2014). Introduction to Earned Schedule Second Edition. Vol. III, Issue XI. PM World Journal.

Lipke, Walt. (2017). Assesing Earned Value Management and Earned Schedule Forecasting. Vol. VI, Issue VIII. PM World Journal.

Lipke, Walt. (2017). Forecasting Schedule Variance Using Earned Schedule. Vol. VI, Issue II. PM World Journal.

Modul Perhitungan Durasi Probabilistik Dengan Metode Earned Schedule Pada Proyek Konstruksi; Hak Kekayaan Intelektual 000107593; Basuki Anondho, Yusuf Latief, Krishna Mochtar; Direktorat Jendral Kekayaan Intelektual, Kementrian Hukum dan Hak Asasi Manusia; 2018.

Poshdar, M., González, V. A., Raftery, G. M., Orozco, F., Romeo, J. S., dan Forcael, E. (2014). A ProbabilisticBased Method to Determine Optimum Size of Project Buffer in Construction Schedules, Journal of Construction Engineering and Management.

Vanhoucke, M., Andrade, P., Salvaterra, F., dan Batselier, J. (2015). Introduction to Earned Duration. The Quarterly Magazine of the College of Performance Management. 